\title{
Phytochemical Analysis and Antibacterial Activity of Annona muricata (Laxman phal) against ESBLs Producers (Escherichia coli and Klebsiella pneumoniae)
}

\author{
N. Kamath $^{1} *$, Rita Swaminathan ${ }^{2}$ and Neetin Desai ${ }^{3}$ \\ ${ }^{1}$ Department of Microbiology, World College of Medical Sciences and Research and Hospital, \\ Jhajjar, Harayana, India \\ ${ }^{2}$ Department of Microbiology, D.Y. Patil School of Medicine and Hospital, \\ Nerul, Navi Mumbai, India \\ ${ }^{3}$ Department of Biotechnology, Amity University, Panvel, Navi Mumbai, India \\ *Corresponding author
}

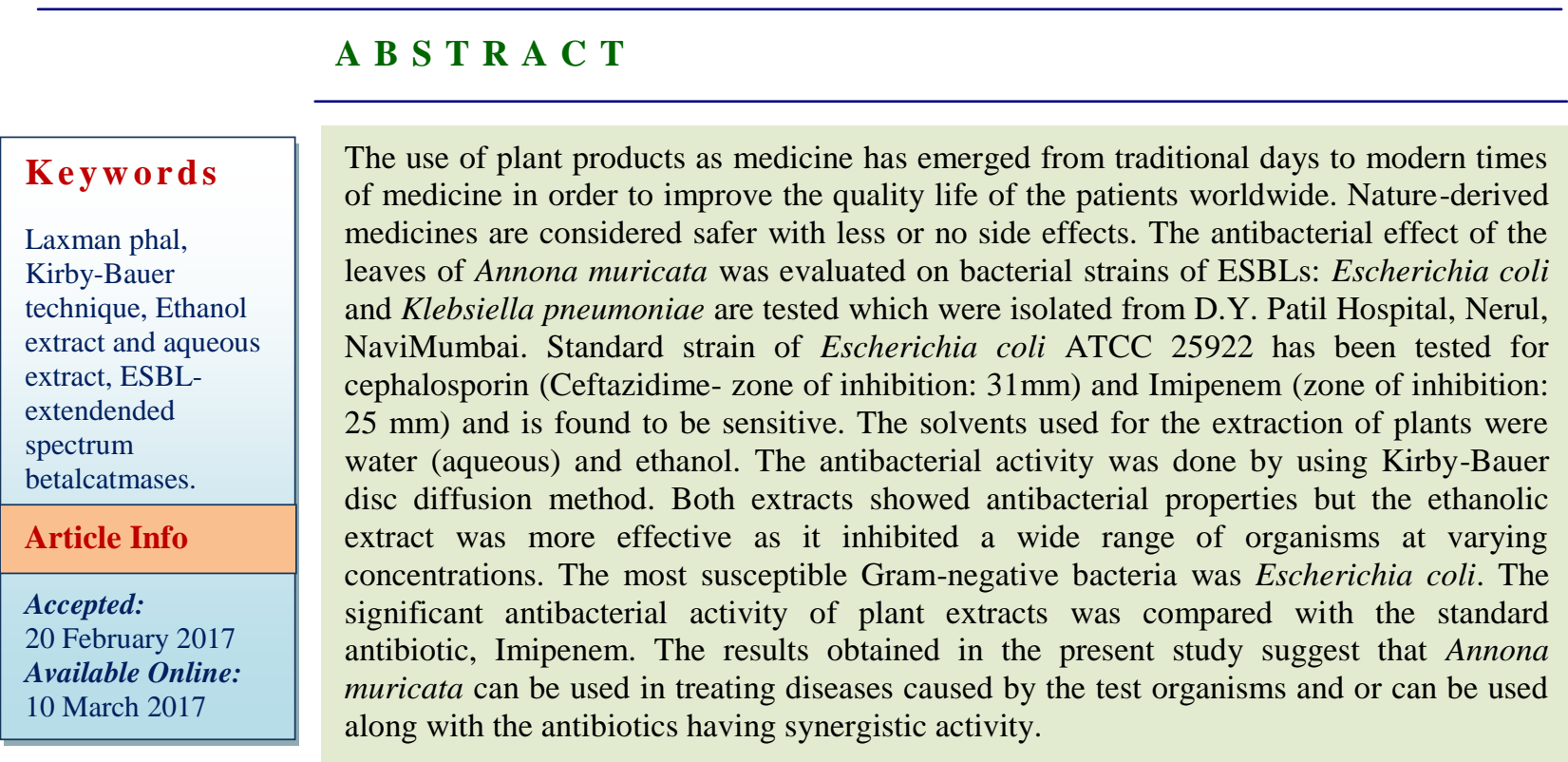

\section{Introduction}

For centuries, quinine, an alkaloid obtained from the bark of various species of cinchona tree has been used in the treatment of malaria; even aspirin and morphine are plant derived drugs from willow bark and opium poppy (Sanjoy et al., 2003). For two thousand years the powdered roots Rauvolfia serpentina has been used in treatment of mental illness in India (Ajay Kumar et al., 2009).
Multidrug resistance has been a biggest threat to the medical world as bacteria are acquiring antibiotic resistance day by day. Interesting conundrums have been encountered in investigations of links between antibiotic use and the development of antibiotic resistance (Julian Davies et al., 2010). Nowadays more and more bacteria are becoming resistant which were earlier sensitive to the antibiotics. 
Newer antibiotics are not invented or slowdown in the process of inventing a newer molecules of antibiotics. The medicinal plants look promising as it has proved in the past like a saviour to the medical world.

Annona muricata is a member of the family of custard apple tree called Annonaceae and a species of the genus Annona known mostly for its edible fruits annona. Annona muricata produces fruits that are usually called 'sour sop' due to its slightly acidic taste when ripe. The fruit is juicy, acidic, whitish and aromatic with abundant seeds, the average weight of 1000 fresh seeds is $470 \mathrm{~g}$ and has an average oil content of $24 \%$. The creamy and delectable flesh of the fruit consist of $80 \%$ water, $1 \%$ protein, $18 \%$ carbohydrates and fair amount of vitamins B1, B2 and C, potassium and dietary fibre. Its flavour is described as a combination of strawberry and pineapple with sour citrus flavour contrasting with an underlying creamy flavour reminiscent of coconut or banana.

Annona muricata has been used as a folkloric herbal medicine in many regions throughout the world. It is considered to be antispasmodic and antiemetic. A decoction of Annona muricata leaves is used to kill bed bugs and head lice to reduce fever (Rickettsial infections or antiparasitic). This can be taken orally or adding to bathing water also has the same effect. The crushed fresh leaves are also applied on skin eruptions for faster healing. A poultice of young Annona leaf is applied on the skin to alleviate rheumatism and other skin infections like eczema. When applied during the healing of wounds, it results in less or no skin scars.

The decoction can also be used as a wet compress on swollen feet and other inflammations. The juice of the fruits is taken orally as an herbal remedy against arthritis, haematuria and liver ailments. Pulverizing the
Annona seed and mixing it with soap and water is used as effective spray against caterpillar. The annona leaves are placed inside the pillow or placed on top of the mattress to induce a good night sleep.

In laboratory studies, annona selectively hunts down and kills 12 different types of cancer cells, including breast, prostate, lung, colon and pancreatic cancer. In view of the usefulness of this plant, there is a need for further research on its antimicrobial properties as well as the determination of its bio-active components.

The leaves are also traditionally used to prevent and treat arthritis, asthma, bronchitis, biliary disorder, diabetes, heart diseases, hypertension, worm disease, liver disorder, malaria, rheumatism, tumour, and cancer. The leaves are also used for the treatment of several types of diseases caused by bacteria such as pneumonia, diarrhoea, urinary tract infection and other kinds of skin diseases.

The objective of this study was to evaluate the phytochemical activity and antibacterial activity of leaves of Annona muricata against extended beta lactamase producers (ESBL) Escherichia coli and Klebsiella pneumoniae as they are multidrug resistant. Multidrug resistance is exhibited by many bacteria and is become a big worry in the world of Medicine.

\section{Materials and Methods}

\section{Plant material and solvent extraction}

Annona muricata leaves were hand-picked from home garden in Kundapur, Udupi District, Karnataka and authenticated. The leaves were washed with distilled water, air dried and then shade dried. The dried leaves were powdered mechanically, subjected to extraction using Soxhelet apparatus with ethanol and distilled water as solvents for up 
to 48 hours. $10 \mathrm{~g}$ of leaves powder was homogenized with $100 \mathrm{ml}$ of solvent with a magnetic stirrer for 30 minutes. Extract was stored at $4^{0} \mathrm{C}$ in airtight bottles for further studies. Escherichia coli is common pathogen which causes Urinary tract infections(UTI), Diarrhoea and Klebsiella pneumoniae causes UTI, respiratory infections and hospital acquired inspections etc.

\section{Bacterial strains}

Multidrug resistant tests strains- i.e., ESBLs were isolated in Microbiology laboratory of D. Y. Patil Hospital, Nerul, Navi Mumbai. Standard strains of Escherichia coli ATCC 25922 was taken from the stock culture. The presence of an ESBL-producing organism in an infection can result in treatment failure if one of the drugs is used ( $2^{\text {nd }}$ Generation cephalosporins). ESBLs can be difficult to detect because they have different levels of activity against various cephalosporins. Thus, the choice of which antimicrobial agents to test is critical. For example, one enzyme may actively hydrolyze ceftazidime, resulting in ceftazidime minimum inhibitory concentrations (MICs) of $256 \mu \mathrm{g} / \mathrm{ml}$, but have poor activity on cefotaxime, producing MICs of only $4 \mu \mathrm{g} / \mathrm{ml}$. If an ESBL is detected, all penicillins, cephalosporins, and aztreonam should be reported as resistant, even if in vitro test results indicate susceptibility as per CLSI (Clinical and Laboratory Standards Institute) guidelines.

\section{Antibacterial testing on ESBLs}

The Whatman no.1 filter paper discs were prepared from $50 \mu \mathrm{l}$ and $100 \mu \mathrm{l}$ of plant extracts and antibiotic sensitivity testing was done by Kirby-Bauer disc diffusion technique by inoculating the bacterial strains (turbidity of the broth was adjusted to $0.5 \mathrm{McFarland}$ standard) on Mueller-Hinton agar by lawn culture and placing the discs with plant extracts and standard antibiotics in triplicate. The plates were allowed to settle for one hour in the room temperature first, then incubated at $37^{\circ} \mathrm{C}$ for $16-24$ hours. Zone of inhibition is measured in millimetres $(\mathrm{mm})$ as compared against standard antibiotics.

\section{Results and Discussion}

Preliminary phytochemical analysis revealed the presence of secondary metabolites like tannins, steroids, cardiac glycosides, etc. were present in the leaves. Table 1 shows the results of the phytochemicals present in Annona muricata leaves. However, the present study of in- vitro antimicrobial evaluation of the leaves of Annona muricata forms a primary platform for further phytochemical and pharmacological studies.

The antibacterial activity of the leaves of Annona muricata extracts was tested in-vitro by Kirby-Bauer Disk diffusion technique against two bacterial species (ESBLs) and one standard strain of antibiotic sensitive bacteria. Table 2 summarizes the microbial growth inhibition of both ethanol and aqueous extracts.

Ethanol extract of Anona muricata(leaves) exhibited antibacterial activity towards all the tested bacteria with high antibacterial activity. The ethanol extracts of the investigated plants showed maximum antibacterial activity than aqueous extract for both E. coli and K.pneumoniae.

It was found that the ethanolic extract of the leaves was effective against Escherichia coli and Klebsiella pneumoniae (both are ESBL producers). The Comparative antibacterial activity between ethanolic extract of Annona muricata and standard antibiotic Imipenem was studied. The ethanolic extract showed significant antibacterial efficacy as compared to the standard antibiotic. 
Zone of inhibition with standard strain E. coli ATCC 25922 showed $25 \mathrm{~mm}$ with aqueous extract of $A$. muricata and with ethanol extract of A. muricata showed $27 \mathrm{~mm}$ which is at par with standard antibiotic disc Imipenem.

Table.1 Phytochemical analysis of the leaves of Annona muricata

\begin{tabular}{|l|c|c|l|}
\hline Tests & $\begin{array}{c}\text { Aqueous } \\
\text { extract }\end{array}$ & $\begin{array}{c}\text { Methanol } \\
\text { Extract }\end{array}$ & Inference \\
\hline $\begin{array}{l}\text { Reducing sugars, } \\
\text { Fehling's test }\end{array}$ & + & + & Carbohydrates Present \\
\hline Starch, Iodine test & - & - & Polysaccharides Absent \\
\hline Test for Steriods & + & + & Steroids Present \\
\hline Keller-Killani test & + & + & Cardiac Glycosides Present \\
\hline Dragendorff's test & - & - & Alkaloids Absent \\
\hline Saponins Absent & - & - & Test for Saponin \\
\hline Borntrager's test & - & - & Anthraquinone Glycoside Absent \\
\hline Ferric chloride test & + & + & Tannins Present \\
\hline Test for Phenolics & - & - & Phenols Absent \\
\hline Test for Flavonoids & - & - & Flavonoids Absent \\
\hline
\end{tabular}

Table.2 Antibiotic susceptibility of the ethanolic (leaves) and aqueous extract (leaves) of Annona muricata

\begin{tabular}{|c|c|c|c|c|}
\hline Test Organisms & $\begin{array}{l}\text { Concentration of } \\
\text { ethanolic extract } \\
100(\mathrm{mg} / \mathrm{ml}) \\
\text { Zone of inhibition } \\
\text { measured in } \mathrm{mm}\end{array}$ & $\begin{array}{l}\text { Concentration of } \\
\text { ethanolic extract } \\
50 \\
(\mathrm{mg} / \mathrm{ml}) \\
\text { Zone of inhibition } \\
\text { measured in mm }\end{array}$ & $\begin{array}{l}\text { Positive control } \\
\text { Imipenem } \\
\text { Zone of inhibition } \\
\text { measured in mm }\end{array}$ & $\begin{array}{l}\text { Negative control } \\
\text { (Ethanol) } \\
50 \mu \mathrm{l} \\
\text { Zone of } \\
\text { inhibition } \\
\text { measured in } \mathrm{mm}\end{array}$ \\
\hline Escherichia coli & $16.5 \pm 0.5$ & $14.0 \pm 0.5$ & $21.0 \pm 0.5$ & 0.00 \\
\hline $\begin{array}{l}\text { Klebsiella } \\
\text { pneumoniae }\end{array}$ & $14.0 \pm 0.5$ & $13 \pm 0.5$ & $23.0 \pm 0.5$ & 0.00 \\
\hline Test Organisms & $\begin{array}{l}\text { Concentration of } \\
\text { aqueous extract } \\
100(\mathrm{mg} / \mathrm{ml}) \\
\text { Zone of } \\
\text { inhibition } \\
\text { measured in } \mathrm{mm}\end{array}$ & $\begin{array}{l}\text { Concentration of } \\
\text { aqueous extract } \\
50 \\
(\mathrm{mg} / \mathrm{ml}) \\
\text { Zone of } \\
\text { inhibition } \\
\text { measured in } \mathrm{mm}\end{array}$ & $\begin{array}{l}\text { Positive control for } \\
\text { Imipenem } \\
\text { Zone of inhibition } \\
\text { measured in mm }\end{array}$ & $\begin{array}{l}\text { Negative control } \\
\text { (distilled water) } \\
50 \mu 1 \\
\text { Zone of } \\
\text { inhibition } \\
\text { measured in mm }\end{array}$ \\
\hline Escherichia coli & $14.5 \pm 0.5$ & $13 \pm 0.5$ & $21.0 \pm 0.5$ & 0.00 \\
\hline $\begin{array}{l}\text { Klebsiella } \\
\text { pneumoniae }\end{array}$ & $13.5 .5 \pm 0.5$ & $13.0 \pm .5$ & $23.0 \pm 00.5$ & 0.00 \\
\hline
\end{tabular}


Picture.1 and 2 Photographs of Annona muricata (leaves and fruit)

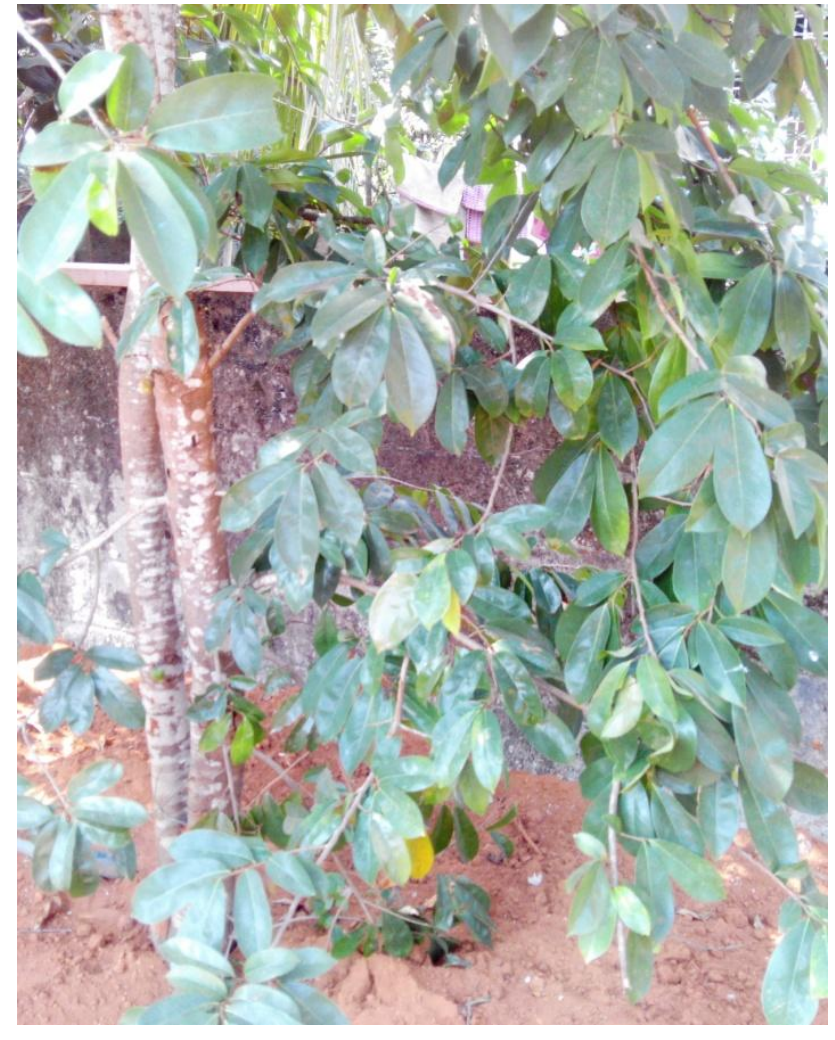

Phytochemical analysis revealed the presence of secondary metabolites like carbohydrates, polysaccharides, steroids, cardiac glycosides and tannins which is also reported by (Julian Davies et al., 2010).

Both aqueous and ethanolic leaves extract of Annona muricata showed antibacterial activity. Ethanolic extract showed higher antibiotic activity which is in line with the previous workers.

Significant $(\mathrm{P}<0.05)$ antibacterial efficacy which can compete with standard antibiotics i.e., Imipenem in ESBLs (Escherichia coli and Klebsiella pneumoniae), the beneficial effects of treatment can be achieved with the treatment with the leaves of Annona muricata in various bacterial infectious diseases like pneumonia, diarrhoea, urinary tract infection, and even some skin disease. It will require a multi-pronged approach that includes the

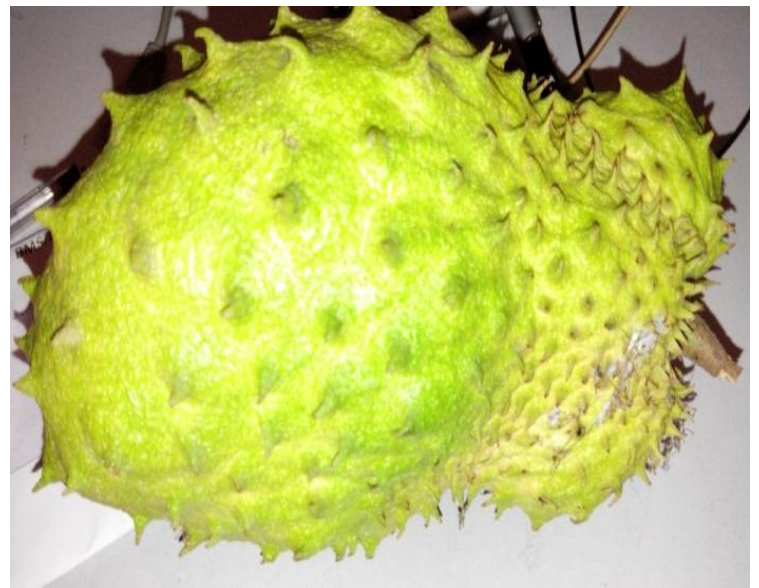

development of new drugs. Using plants as the inspiration for new drugs provides an infusion of novel compounds or substances for healing disease (Iwu et al., 1999). Annona muricata (soursop) is a potent anticancer plant of Annonaceae family. The therapeutic potentials of the n-butanolic extract of Annona muricata were studied on WRL-68, MDA-MB-435S and HaCaT cell lines. Since most of the chemotherapeutic drugs affect normal cells as well, WRL- 68 cells were analysed for the relative cytotoxic response in with comparison that quantified in MDA-MB435S and $\mathrm{HaCaT}$ cell lines. n-Butanolic leaf extract of A. muricata possess significant anticancer potentials in humancancerous cells. Plant phenolics are a major group of compounds that act as primary antioxidants or free radical scavengers. Broad spectrum of antibacterial activity and phytochemical activity is exhibited by Annona muricata. According to Parbha Pathak et al., (2010) 
most susceptible bacteria was $K$. pneumoniae with Annona muricata leaves extract. Isolation of two new Annonaceous acetogenins, annocatacin $\mathrm{A}$ and annocatacin $B$ from the seeds and the leaves which is proved to be which showed in-vitro cytotoxicity towards human hepatoma cell lines (Chang et al., 2003). The plant possess the major pharmacological activities includes cytotoxic, antileishmanial, wound healing, anti-microbial activity (Geetalaxmi et al., 2012). ESBLs show antibiotic resistance $(<10 \mathrm{~mm})$ in disc diffusion technique and the results with leaves extracts show better activity than cephalosporins.

In conclusion, Annona muricata extract possesses a broad spectrum of activity against ESBL producers (Escherichia coli and Klebsiella pneumoniae) which responsible for the most common bacterial diseases. Ethanolic extracts showed better antibacterial activity when compared with aqueous extracts. Phytochemicals present in the leaves support the antibacterial activity. These promissory extracts open the possibility of finding new clinically effective antibacterial compounds. Leaves extracts have good antibacterial activity which can supplement moderately sensitive antibiotics. So combined activity can prove to be beneficial in treating the patients suffering from ESBL producing bacteria. Leaves extract of Annona muricata has lot to promise in further years to come by biomedical research.

\section{References}

Ajay Kumar Meena, Parveen Bansal, Sanjiv Kumar. 2009. Plants-herbal wealth as a potential source of ayurvedic drugs, Asian J. Traditional Med., 4(4).

Biba, V.S., Amily, A., Sangeetha, S., and Remani, P. 2014. Anticancer, antioxidant and antimicrobial activity of Annonaceae family, Vol. 3, Issue 3, 1595-1604.

Chang, F.R., Liaw, C.C., Lin, C.Y., Chou, C.J., Chiu, H.F., Wu, Y.C. 2003. New adjacent Bis-tetrahydrofuran Annonaceous acetogenins from Annona muricata, Europe Pub med Central Planta Medica, 69(3): 241-246.

Geetalaxmi, S., Vijayalaxmi, S. and Devi Rajesswari, V. 2012. Phytochemical and pharmacological properties of Annona muricata: A Review, Int. J. Pharm. Pharma. Sci., Vol 4, Issue 2.

Iwu, M.M., Duncan, A.R., and Okunji, C.O. 1999. New Antimicrobials of Plant Origin, J. Natural Products, 457-462.

Julian Davies and Davies. 2010. Origins and Evolution of Antibiotic Resistance, Microbiol. Mol. Biol. Rev., 74(3): 417433.

Pathak, Saraswathy, D., and Vora, S. 2010. In vitro antimicrobial activity and phytochemical analysis of the leaves of Annona muricata, Int. J. Pharma. Res. Develop., (5): 1-6.

Sanjoy Kumar Pal, Yogeshwer Shukla. 2003. Asian Herbal Medicine: Current Status and the Future, Pacific J. Cancer Prev., Vol. 4: 281-288

\section{How to cite this article:}

Kamath, N., Rita Swaminathan and Neetin Desai. 2017. Phytochemical analysis and antibacterial activity of Annona muricata (Laxman phal) against ESBLs producers (Escherichia coli and Klebsiella pneumoniae). Int.J.Curr.Microbiol.App.Sci. 6(3): 1339-1344.

doi: https://doi.org/10.20546/ijcmas.2017.603.155 